\title{
Presença da Diferença: Uma análise da atuação política de mulheres parlamentares (2003-2006)
}

\author{
Gabriela Oliveira de Andrade \\ Orientador: Prof. Dr. Michelangelo Giotto Santoro Trigueiro \\ Curso: Doutorado em Sociologia \\ Data da Defesa: 20.12.2012
}

E

sta pesquisa tem por objetivo abordar as relações existentes entre gênero, representação e participação política. Uma das questões centrais é entender como foram condicionadas as práticas políticas femininas e em que medida isso afeta a participação e produção legislativas de homens e mulheres no Congresso Nacional. Para tanto, foi realizado um levantamento exaustivo sobre a participação dos/as parlamentares nas comissões existentes, bem como sobre informações a respeito das trajetórias políticas e biográficas, além da verificação dos temas abordados nas proposições apresentadas no período da 52 a legislatura (2003-2006) que permitissem compreender as formas de atuação política de homens e mulheres. Os resultados apontam para uma concentração das mulheres no campo dos temas sociais, principalmente nos temas que são tradicionalmente atrelados às mulheres na esfera privada, revelando que elementos caracterizadores de dominação e subordinação que ocorrem no campo privado possuem reflexos sobre a atuação parlamentar feminina. Cabe destacar, ainda, as práticas legislativas dos homens, que concentram a produção de seus projetos e a participação em comissões em temas de cunho político-legal e econômico. Embora haja uma tendência de distribuição mais equilibrada das mulheres e, em especial das senadoras, sobre os temas que abordam em suas proposições, não é possível afirmar que essa tendência se confirmará. Além disso, alguns elementos são percebidos como importantes na compreensão das práticas legislativas de homens e mulheres parlamentares: a socialização diferenciada, o sexismo institucional reproduzido e reforçado no parlamento, o habitus engendrado, as limitações do campo político impostas pelos jogos de poder e o capital político acumulado e exigido ao exercício do cargo parlamentar. A análise, como um todo, mostrou não só a concentração dos e das congressistas em áreas temáticas distintas, mas apontou também a ausência de mulheres de determinados campos temáticos, revelando os entraves a uma inclusão efetiva de mulheres nas arenas de decisão política.

Palavras-chave: Mulheres, Participação Política, Representação Política, Congresso Nacional, Câmara dos Deputados, Senado Federal. 